however, the flow of fluid becomes so abundant as to constitute an actual stream; it continues to flow for some time, but gradually diminishes in quantity, and at length ceases, and with it the pain in the stomach. The latter is the characterising symptom of alkaline dyspepsia, or pyrosis, as it has been frequently termed. But hitherto it has always been confounded with other forms of indigestion. Dr. Prout has published an account of his examination of the fluid of pyrosis, and has stated that it was acid; the fluid, however, was not procured by himself, but was sent him from one of the hospitals, where the mistake was very likely to occur. This form of indigestion occurs much more frequently than is generally imagined. Dr. Thomson stated that out of 40 or 50 patients daily seen at the Blenheim-street Dispensary, in London, he generally met with one or two affected with symptoms of this description. It frequently occurred in coincidence with affections of other organs-as of the uterus, liver, \&c., and was often of such a pressing nature that it required more of the skill of the medical man than the original disease. Certain it was that it was absolutely necessary to treat it with as much care as the original complaint, and if the action had been allowed to go on for some time unchecked, the secondary affection became as firmly fixed as the original disease which had induced it; so that after the removal of the latter a second disease, as firmly rooted as the first, required to be taken under the physician's care; the treatment consisted of the administration of acids, tonics, and narcotics, which required to be prescribed with care, otherwise the acid indigestion was frequently induced, which was as difficult to eradicate as the alkaline form.

3. The last form of indigestion, as indicated by the fluid ejected by the mouth, which the author had met with, was a neutral state, which was of much rarer occurrence. Dr. Thomson had, however, met with several cases, and had succeeded in overcoming the disease by the use of tonics.

\section{HILL COOLIES IN BRITISH GUIANA.}

\section{To the Editor of THE LANCET.}

SrR :-Having been out of town for some time it was only yesterday that I had an opportunity of reading an article in THE LANCET of the 24th ultimo, on the subject of the Coolies lately imported into British Guiana.

I assure you, $\mathrm{Sir}$, that no one can regret more sincerely than I do the dreadful sufferings to which some of these unfortunate people have been subjected; nor can I attempt to palliate the conduct which has too evidently been adopted towards them, on more than one of the estates on which they have been placed. Some of your observa. tions, however, are so very incorrect, others so personal to myself, that I hope you will allow me to say a few words in reply.

After some preliminary remarks about slavery, \&c., and the small scale of wages to be given, you go on to say :- "We follow the first cargo on board the Whitby, comprising 266 men, 8 women, and 11 children. The ship sailed from Calcutta Jan. 6,1838 , and arrived at Berbice the 6th of May; in the interval of four months fifteen men died." If you will take the trouble to read the printed returns to which you have alluded, you will find that only eight men died on the passage, one of whom (and the only good man we lost) died suddenly the day that we made Berbice. Your "probability that in the time not one would have died at home out of the number," is absurd; but if you will look at the average number of deaths in emigrant ships from this country to New South Wales and Australia, you will see that it is donble what it was in the Whitby. You say that I do not satisfactorily account for the rapid spreading of disease at Dimond Harbour and Mud Point, at the same time you very kindly supply the deficiency with, "It can only be ascribed to the accumulation of 285 persons, besides the crew, between the decks of a small vessel." On most subjects I am inclined to place considerable weight on the professional opinion of the editor of THE LANCET, bat on this point we differ most widely. The Whitby is about 500 tons burden (O.M.) has a clear" between decks" 86 feet in length, 29 feet beam, and six feet six inches in height; and with all due deference to your superior judgment is capable of taking, with the utmost safety, 300 persons, besides her crew, to any part of the world.

The censure cast on the highly respectable individuals who have introduced these people into British|Guiana, is very unmerited. No persons could have been more anxious than Messrs. Colvile and Davidson that every kindness should be shown to them on their arrival. That their benevolent intentions have not been carried into effect is deeply to be lamented. My orders were, to spare no expense in procuring for them whatever I might consider pecessary for their health, or that would add to their comfort on the passage. That I did so, I refer to Captain Swinton, than whom a more humane or more honourable man does not exist, and I can safely say that no persons could be more happy than during the five wonths they were under my charge.

The propriety of allowing the natives of India to emigrate is a question of the utmost importance. I should be glad if the antislavery gentlemen would for a short time lay aside their interested motives, and instead of denouncing punishment, here and 
hereafter, on all who were concerned in this not know whether the case was published affair, consider that in the Presidency of in your periodical, and shall therefore copy Bengal alone there are hundreds of thon- it as it stands in my journal.

sands of their fellow creatures, for eight months in the year, in a state of starvation. In some districts hundreds are carried off daily from famine and its consequences, while others, driven to despair, form themselves into marauding bands, committing the most horrible crimes, and carrying terror and dismay wherever they appear. Yet these people are most anxious to work when they can find employment, even for the most scanty pittance; there is also a general wish to emigrate, thousands coming annually to Calcutta alone, for that purpose. Why they should not be allowed to do so, where there is a certainty of bettering their condition, I am unable to divine. In British Guiana, one of the finest and most productive colonies belonging to this country, there is work for upwards of a hundred thousand additional labourers. The soil and climate are very similar to a great part of India. That the Indians will enjoy their health there when properly attended to, is proved by the state of the Coolies in Anna Regina, on the west coast of Demerara; and I am well convinced if emigration vere allowed to this colony, under proper restrictions at Calcutta, and strict regulations for their treatment on their arrival, it would be of the utmost consequence to India, by providing for part of her superabundant population, while it would be of incalculable benefit both to this country and British Guiana.

With every apology for trespassing so long on your valuable time, I am, $\mathrm{Sir}$, your obedient servant,

London, Sept. 11, 1839.

\section{A. S. WISEMaN.}

\section{BITE OF A RATTLESNAKE.}

To F. Corey , Esq., Garrison Surgeon, Furt William, Calcutta, Editor of the "India Medical Journal."

MY dear Sir :-I feel much pleasure in accepting the permission of the Editor to make this communication to you through the medium of The Lancet. You may probably remember a case I transmitted to you for insertion in the "India Medical Journal" of December, 1837, describing the symptoms and result of a bite inflicted on an officer of H.M.B. Algerine, by a snake, the name, \&c., of which we could not discover, although we passed a considerable time in the attempt. On my return to Eng. land in the following year, I accidentally, in a bookseller's shop, discovered a draw. ing and description of a snake so precisely similar to the one in question that $I$ copied the description, intending, when an opportunity offered, to tra nsmit it to you. I do
Madras, October 9th, 1837.-In consequence of a message from the commander of the Algerine, I went on board that brig, and found Mr. Hayman, one of the officers, in the following state:-Countenance extremely anxious, and covered with a cold and clammy perspiration; great difficulty of breathing; pulse weak and irregular; lips covered with saliva, and great horror exhibited on being presented with any liquid. On inquiry I found that about two hours previously he had been bitten by the reptile which the crew had taken from alongside the ship while washing decks. After receiving the injury he had gone below and taken a bearty breakfast, and while standing on deck, about an hour afterwards, he, to use the words of his brother officer, " squinted horribly, and fell down in a fit," when, their own surgeon being engaged on shore, they had sent to our ship. As the probable termination was so evident I expressed my wish to the commanding officer that a further opinion might be procured, and he dispatched a boat to the Minerva Indiaman, which shortly returned with $\mathrm{Mr}$. Grant, surgeon to that ship. In the meanwhile I examined the wound, which was barely perceptible, and situated at the junction of the finger with the thumb of the right hand, and having first applied a ligature at the wrist, I endeavoured to induce him to swallow a draught (ammonia in brandy and water); but I found deglatition utterly impracticable.

On Mr. Grant's arrival these efforts were renewed, and mustard plasters were applied to his calves, but all exertions were fruit. less : he gradually sank and expired, apparently without pain, about four hours after the receipt of the bite. I felt for a long time subsequently much anxiety as to the treatment which had been adopted, and was not a little relieved to find that the bite of this snake is by the natives considered " inevitably fatal."

\section{"XIV. \\ " PSEUDOBOA FASCIATA.}

"Gen. Char.-Plates on the belly and under the tail single; head short, covered with large plates; back carinated with a longitudinal row of larger scales. Specific Character,-Body subtriangular, yellowish, with numerous dusky-blue, transverse bands. Length six feet; called by the natives bungarum pamah. This species, which may be ranked among the most formidable of the poisonous serpents, inbabits India, and is said not to be unconmon in the country of Bengal. It is a large snake, measuring six or seven feet in length, the diameter in the thickest part being nearly five inches. It is of a yellowish colour, marked with numerous blue dusky, transverse bands, each band 